\title{
LETTER
}

\section{Ethane- and hydrogen-bearing carbonic fluid inclusions in a high-grade metamorphic rock}

\author{
Toshiaki TsunOGAE ${ }^{* * *}$ and Jean DUBESSY ${ }^{* * *}$ \\ *Graduate School of Life and Environmental Sciences (Earth Evolution Sciences), \\ University of Tsukuba, Ibaraki 305-8572, Japan \\ ${ }^{* *}$ Department of Geology, University of Johannesburg, Auckland Park 2006, \\ Johannesburg, Republic of South Africa \\ ${ }^{* * *} G^{2} R(U M R$ 7566), Nancy Université and CNRS, BP70239, \\ F-54506 Vandoeuvre-lès-Nancy Cedex, France
}

\begin{abstract}
Ethane- and hydrogen-bearing carbonic fluid inclusions are found within quartz in a leucocratic garnet granulite obtained from the Neoarchean Limpopo Belt in South Africa. The trapped fluids are present as secondary inclusions and show melting temperatures in the range of -60.9 to $-56.9{ }^{\circ} \mathrm{C}$, suggesting a dominantly $\mathrm{CO}_{2}-$ rich composition. The wide range of estimated $\mathrm{CO}_{2}$ densities $\left(0.611-1.020 \mathrm{~g} / \mathrm{cm}^{3}\right)$ indicates entrapment of the fluids at $5 \mathrm{kbar}$ at $700{ }^{\circ} \mathrm{C}$ and significant subsequent density decrease due to post-peak decompression. Laser Raman analysis of the inclusions at room temperature confirmed that the trapped fluids are $\mathrm{CO}_{2}$-rich ( $>95$ mol\%) with very minor $\mathrm{CH}_{4}(2.5-4.6 \mathrm{~mol} \%), \mathrm{N}_{2}(0.1-0.4 \mathrm{~mol} \%)$, and $\mathrm{C}_{2} \mathrm{H}_{6}(0.01-0.02 \mathrm{~mol} \%)$ constituents. A thin carbon film precipitated on the cavity wall, not visible optically, was also identified by Raman spectroscopy. We therefore infer the following carbon-forming reaction during decompression and/or cooling below $700{ }^{\circ} \mathrm{C}$ and 5 kbar; $\mathrm{CO}_{2}+\mathrm{CH}_{4} \rightarrow 2 \mathrm{C}+2 \mathrm{H}_{2} \mathrm{O}$. When the inclusions were heated to $150{ }^{\circ} \mathrm{C}$ to homogenize all the fluid phases, $\mathrm{H}_{2}(0-0.05 \mathrm{~mol} \%)$ and $\mathrm{H}_{2} \mathrm{O}(1.7-0.3 \mathrm{~mol} \%)$ were detected instead of $\mathrm{C}_{2} \mathrm{H}_{6}$. Although the processes of the formation of $\mathrm{C}_{2} \mathrm{H}_{6}$ and $\mathrm{H}_{2}$ are not known, the presence of $\mathrm{CH}_{4}, \mathrm{C}_{2} \mathrm{H}_{6}$ and $\mathrm{H}_{2}$ in $\mathrm{CO}_{2}$-dominant fluid is considered as a possible product of a series of reactions in the $\mathrm{C}-\mathrm{O}-\mathrm{H}$ system within the inclusion cavity during decompression/cooling.
\end{abstract}

Keywords: Carbonic fluid, Ethane, Hydrogen, Raman spectroscopy, Granulite, Limpopo Belt

\section{INTRODUCTION}

It is well known that fluids in the lower crust play an important role in the stability and transformation of mineral assemblages during high-grade metamorphism (e.g., Newton et al., 1980). For the characterization of geological fluids, fluid inclusions trapped in various minerals provide the route to obtain direct information on their chemical and physical properties. Laser Raman spectroscopy is a powerful tool for the identification and quantification of fluids trapped in minerals, and the technique has been used in a number of fluid inclusion studies (e.g., Wopenka and Pasteris, 1986; Dubessy et al., 1989). In the present study, we carried out combined microthermometric and laser Raman spectroscopic studies of fluid inclusions in granulite-facies rocks from the Limpopo Belt in South

doi:10.2465/jmps.090622f

T. Tsunogae, tsunogae@geol.tsukuba.ac.jp Corresponding author J. Dubessy, Jean.Dubessy@g2r.uhp-nancy.fr
Africa to characterize fluids related to Neoarchean highgrade metamorphism. Although previous fluid inclusion studies on the Limpopo Belt reported the presence of $\mathrm{CO}_{2}$-rich fluid during high-grade metamorphism (e.g., van Reenen and Hollister, 1988; van den Berg and Huizenga, 2001; Tsunogae and van Reenen, 2007), our additional study on leucocratic gneiss from the belt identified methane, ethane, and hydrogen in the dominantly $\mathrm{CO}_{2}{ }^{-}$ rich fluid, which have so far not been reported for highgrade metamorphic rocks.

A leucocratic garnet gneiss sample (sample IIC1) was collected from Bandelierkop Quarry in the Southern Marginal Zone of the Limpopo Belt. Detailed petrologic and geothermobarometric studies on the locality have been carried out by Stevens and van Reenen (1992). The dominant mineral assemblage of the rock is composed of garnet, plagioclase, $\mathrm{K}$-feldspar, and quartz, suggesting its partial-melting origin from pelitic granulite during prograde metamorphism. Fluid inclusions were studied in 


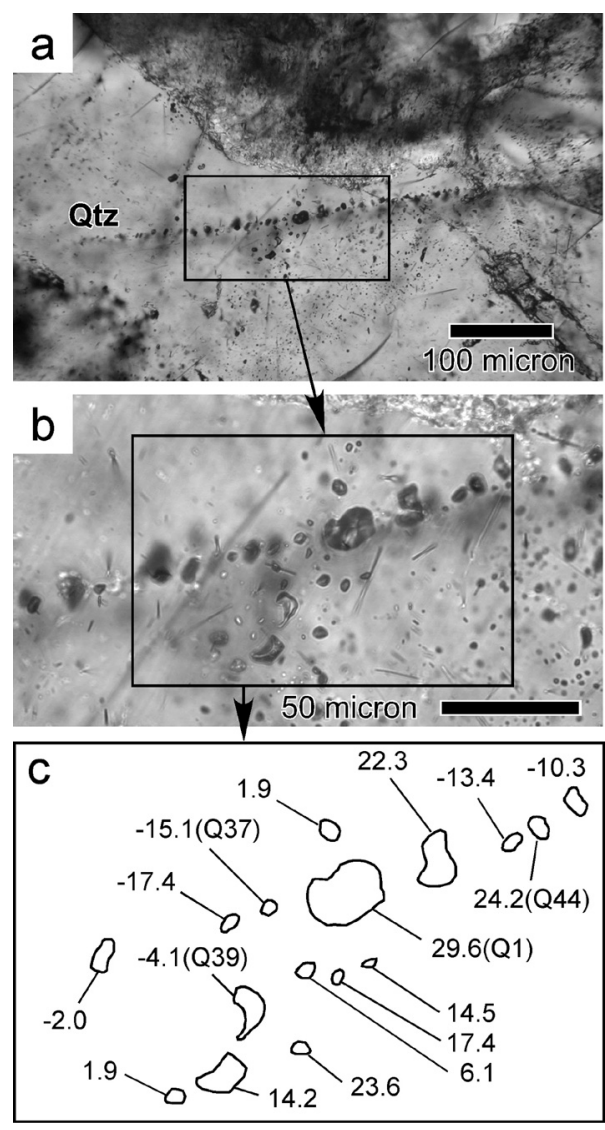

Figure 1. Photomicrographs and a sketch of the representative fluid inclusions in quartz obtained from the Limpopo Belt in South Africa. (a) A trail of secondary inclusions in quartz discussed in this study. (b) Enlargement of (a). (c) A sketch of secondary fluid inclusions shown in (b). Numbers indicate homogenization temperatures as discussed in the text. Q1 to Q44 are inclusion numbers for laser Raman analysis (see Table 2).

doubly polished thin (150 to $200 \mu \mathrm{m})$ wafers. They are present only in large quartz grains (Fig. 1a). The inclusions are ovoidal or irregular in shape, and their size varies from 2 to $20 \mu \mathrm{m}$. They are aligned along linear arrays that cut across the host quartz crystal and thus are secondary (Figs. 1a and 1b). No primary fluid inclusion was found.

\section{MICROTHERMOMETRY}

Microthermometric measurements were performed using a USGS heating/cooling stage at the University of Tsukuba. The detailed analytical procedure using the instrument has been summarized by Tsunogae et al. (2002). The results of the microthermometric measurements are shown in Figure 2 and are summarized in Table 1, which are available online from http://www.jstage.jst.go.jp/browse/ jmps. Fluid densities and isochores (lines of constant volume) were calculated using the computer program "FLIN-

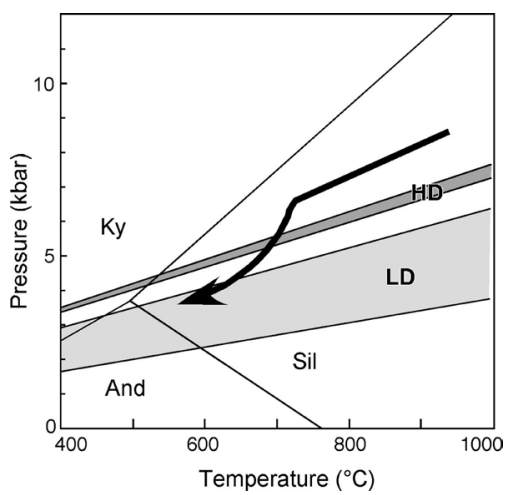

Figure 3. $P-T$ trajectory of the Southern Marginal Zone of the Limpopo Belt (modified after Tsunogae et al., 2004) with isochores for carbonic fluid inclusions estimated in this study. The isochore for the highest-density inclusion (HD; Table 1) is plotted separately from the other low-density inclusions (LD).

COR" developed by Brown (1989), based on the equation and thermodynamic data of Brown and Lamb (1989). For the isochore calculations, all the analyzed carbonic fluid inclusions are regarded as pure $\mathrm{CO}_{2}$ since the trapped fluids contain more than $95 \mathrm{~mol} \% \mathrm{CO}_{2}$, as discussed in the next section.

Fluid inclusions display melting temperatures $\left(\mathrm{CO}_{2}\right.$ solid $+\mathrm{L}+\mathrm{V} \rightarrow \mathrm{L}+\mathrm{V}$ at $T_{\mathrm{m}}$ ) between -60.9 and $-56.9^{\circ} \mathrm{C}$, with more than $90 \%$ of the $T_{\mathrm{m}}$ between -58.3 and $-56.9^{\circ} \mathrm{C}$, indicating that the dominant fluid trapped in quartz is $\mathrm{CO}_{2}$-rich and additional components are present. All the inclusions homogenized into the liquid phase. Most of them show a wide homogenization temperature $\left(T_{\mathrm{h}}\right)$ range of -4.1 to $+29.6{ }^{\circ} \mathrm{C}$, which corresponds to $\mathrm{CO}_{2}$ densities of 0.611 to $0.952 \mathrm{~g} / \mathrm{cm}^{3}$. In contrast, rare high-density inclusions $\left(T_{\mathrm{h}}=-10.3\right.$ to $-17.4{ }^{\circ} \mathrm{C}, d=0.985$ to $1.020 \mathrm{~g} /$ $\mathrm{cm}^{3}$ ) were also found together with the low-density inclusions (Table 1). Such wide density variation and preservation of the rare high-density inclusions in the same inclusion array (see Fig. 1c) suggest that even though all the fluid inclusions were probably trapped together, some inclusions underwent significant density decreases during decompression from a high-pressure stage (e.g., Ohyama et al., 2008; Tsunogae et al., 2008; Nishimiya et al., 2008). The highest-density inclusions were used for calculation of a specific isochore in the $P-T$ space (Fig. 3). The estimated $\mathrm{CO}_{2}$ isochores for the high-density inclusions intersect the clockwise $P-T$ trajectory of the study area at around $5 \mathrm{kbar}$ at $700{ }^{\circ} \mathrm{C}$ (Fig. 3), which corresponds to a retrograde decompression stage. The carbonic fluids were probably trapped along the cracks in quartz formed by post-peak rapid pressure decrease. 

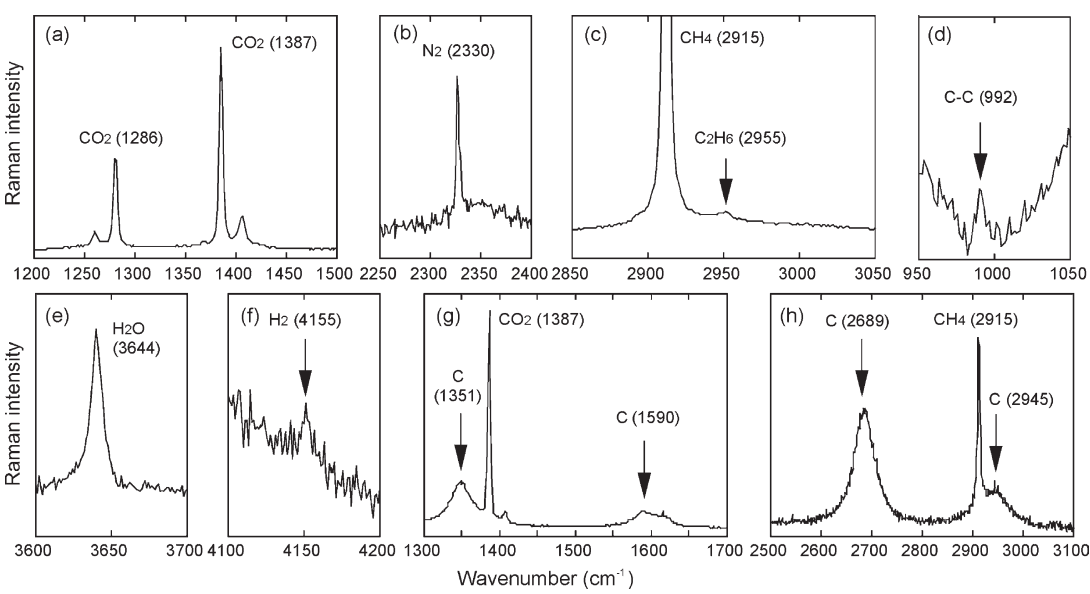

Figure 4. Raman spectra of representative fluid and solid inclusions discussed in this study. (a) $\mathrm{CO}_{2}$ in inclusion Q1. (b) $\mathrm{N}_{2}$ in inclusion Q1. (c) $\mathrm{CH}_{4}$ and $\mathrm{C}_{2} \mathrm{H}_{6}$ in inclusion Q1. (d) Signal of $\mathrm{C}-\mathrm{C}$ vibration of $\mathrm{C}_{2} \mathrm{H}_{6}$ in inclusion Q1. (e) $\mathrm{H}_{2} \mathrm{O}$ in inclusion Q44. (f) $\mathrm{H}_{2}$ in inclusion Q44. $(\mathrm{g})$ and $(\mathrm{h})$ Carbon in inclusion Q1.

\section{LASER RAMAN ANALYSIS}

The molar ratios of gas phases in individual fluid inclusions were analyzed by laser Raman spectroscopy using a (BDilor Labram type Raman spectrometer at $G^{2} R$, Nancy, with an ${ }^{\circledR}$ Edge filter and a CCD detector cooled at $-140{ }^{\circ} \mathrm{C}$. The excitation radiation at $514.532 \mathrm{~nm}$ was provided by an $\mathrm{Ar}^{+}$laser (type 2020, ${ }^{\circledR}$ Spectraphysics). The laser is focused onto the sample with a $\times 80$ objective $(\infty$; n.a. $=$ 0.75 ; ${ }^{\circledR}$ Olympus). The minimal spatial resolution is around $1 \mu \mathrm{m}$ on surface sample but deteriorates slightly inside the sample due to refraction. The laser power at the sample is around $60 \mathrm{~mW}$. Raman data were obtained at room temperature $\left(25^{\circ} \mathrm{C}\right)$ and also at $150{ }^{\circ} \mathrm{C}$ after homogenizing all the fluid phases within the inclusion cavities using a Linkam heating/cooling stage for comparison. Raman spectra of $\mathrm{CO}_{2}, \mathrm{CH}_{4}, \mathrm{~N}_{2}, \mathrm{H}_{2} \mathrm{O}, \mathrm{C}_{2} \mathrm{H}_{6}$, and $\mathrm{H}_{2}$ for representative fluid inclusions are shown in Figures $4 \mathrm{a}$ to $4 \mathrm{f}$. $\mathrm{C}_{2} \mathrm{H}_{6}$ was identified by three Raman active vibrational Raman modes, $2955 \mathrm{~cm}^{-1}$ (antisymmetric stretching), 2899 $\mathrm{cm}^{-1}$ (symmetric stretching), and at $992 \mathrm{~cm}^{-1}$ (C-C stretching mode), (Herzberg, 1945) (Figs. 4c and 4d). No peaks of $\mathrm{CO}, \mathrm{H}_{2} \mathrm{~S}$, and $\mathrm{SO}_{2}$ were detected. Estimates of relative molar ratios of fluid species in the inclusions were determined based on peak ratios (Dubessy et al., 1989).

Temperature should a priori affect the quantification procedure since the differential scattering Raman crosssection is inversely proportional to $1-\exp \left(-h c v_{j} / k T\right)$ (Eckhardt and Wagner, 1966; Schrötter and Klöckner, 1979) where $v_{j}$ is the wavenumber of the considered vibrational mode and $h, c, k$ and $T$ are the Planck constant $(h)$, the speed of light $(c)$, the Boltzmann constant $(k)$ and the absolute temperature $(T)$. Therefore, the differential Raman scattering cross-sections at temperature $T$ is such as:

$$
\frac{d \sigma_{j}}{d \Omega}\left(v_{0}, T\right) \prec\left(1-\exp \left(-h c v_{j} / k T\right)\right)^{-1}
$$

where $v_{0}$ is the wavenumber of the laser excitation. Thus, the ratio between the differential Raman scattering crosssection at temperature $T$ and $T_{0}$ is:

$$
\begin{aligned}
& {\left[\frac{d \sigma_{j}}{d \Omega}\left(v_{0}, T\right)\right] /\left[\frac{d \sigma_{j}}{d \Omega}\left(v_{0}, T_{0}\right)\right]} \\
& \quad=\left[1-\exp \left(-h c v_{j} / k T_{0}\right)\right] /\left[1-\exp \left(-h c v_{j} / k T\right)\right]
\end{aligned}
$$

For the band of $\mathrm{CO}_{2}$ at $1388 \mathrm{~cm}^{-1}$, and for $T_{0}=293$ $\mathrm{K}$, and $T=423 \mathrm{~K}$, the value of this ratio is 1.0083 . Same approach can be done for the Raman scattering cross-section of the symmetric stretching band of water vapour at $3657 \mathrm{~cm}^{-1}$. At $423 \mathrm{~K}$, the ratio is even smaller: 1.000003975. The effect of temperature is therefore negligible for this temperature interval range. The calibration of the analysis of $\mathrm{CO}_{2} / \mathrm{H}_{2} \mathrm{O}$ ratio in $\mathrm{CO}_{2}$-rich fluid is in progress, but we did not take into account the effect of temperature as the aim of this paper is to get an estimation of the water content. The Raman scattering cross-section of ethane was taken from data of Lapp and Penney (1977) and that of vapour water from Schrötter and Klöckner (1979).

Raman analyses of the inclusions (Tables 2, and 3; Table 3 is available online from http://www.jstage.jst. go.jp/browse/jmps) indicate that the fluids are composed dominantly of $\mathrm{CO}_{2}(95-97 \mathrm{~mol} \%$; Fig. 4a) with minor amounts of $\mathrm{N}_{2}$ (0.1-0.4 mol\%; Fig. 4b), $\mathrm{CH}_{4}$ (2.5-4.6 mol\%; Fig. 4c), and $\mathrm{C}_{2} \mathrm{H}_{6}(0.01-0.02 \mathrm{~mol} \%$; Figs. $4 \mathrm{c}$ and 4d) at $25^{\circ} \mathrm{C}$. If the inclusions were heated at $150{ }^{\circ} \mathrm{C}, \mathrm{H}_{2} \mathrm{O}$ (1.7-0.3 mol\%; Fig. 4e) and $\mathrm{H}_{2}$ (0-0.05 mol\%; Fig. 4f) were also detected as minor components, but the Raman peak of $\mathrm{C}_{2} \mathrm{H}_{6}$ disappeared at this temperature. Identification of $\mathrm{H}_{2} \mathrm{O}$ at $150{ }^{\circ} \mathrm{C}$ results from bulk homogenization of the inclusion which contained an invisible film of water wetting the inclusion wall. Thin films of carbon between the trapped fluid and the inclusion wall from three inclu- 
Table 2. Molar abundance of fluids trapped in individual fluid inclusions in sample IIC1

\begin{tabular}{lcccccccc}
\hline No. & $\mathrm{T}\left({ }^{\circ} \mathrm{C}\right)^{*}$ & $\mathrm{CO}_{2}(\mathrm{~mol} \%)$ & $\mathrm{CH}_{4}(\mathrm{~mol} \%)$ & $\mathrm{N}_{2}(\mathrm{~mol} \%)$ & $\mathrm{C}_{2} \mathrm{H}_{6}(\mathrm{~mol} \%)$ & $\mathrm{H}_{2}(\mathrm{~mol} \%)$ & $\mathrm{H}_{2} \mathrm{O}(\mathrm{mol} \%)$ & Carbon \\
\hline Q1 & 25 & 97 & 2.5 & 0.1 & 0.02 & n.d. & n.d. & yes \\
Q37 & 25 & 95 & 4.6 & 0.4 & 0.01 & n.d. & n.d. & yes \\
Q39 & 150 & 99 & 1.1 & n.d. & n.d. & n.d. & 0.3 & no \\
Q44 & 150 & 96 & 1.9 & n.d. & n.d. & 0.05 & 1.7 & yes \\
\hline
\end{tabular}

Occurrences of carbon in the inclusions are also described in the Table.

* Temperature at the Raman analysis.

n.d., not detected.

sions (Figs. 4g, 4h, and Table 2) were only identified by Raman spectroscopy but were not visible under optical microscope, indicating probably less than 30 graphene layers are present. This suggests that carbon probably precipitated from the $\mathrm{CO}_{2}$-rich fluid after entrapment.

\section{DISCUSSION}

Secondary $\mathrm{CO}_{2}$-rich fluids trapped in quartz grains were identified in leucocratic garnet gneiss from the Limpopo Belt in South Africa. Microthermometric measurements and the secondary nature of the fluid inclusions indicate these $\mathrm{CO}_{2}$-rich fluids were trapped during the post-peak decompression stage, approximately $700{ }^{\circ} \mathrm{C}$ at $5 \mathrm{kbar}$. Although such $\mathrm{CO}_{2}$-rich fluids have been regarded as a peak metamorphic fluid in granulite-facies rocks worldwide (e.g., Touret, 1971), we could not find any peak metamorphic fluids in the examined sample, possibly because the peak metamorphism was fluid-absent or the trapped fluids are no more in the inclusion cavity. The $\mathrm{CO}_{2}$-rich secondary fluids contain minor fluid components: $\mathrm{CH}_{4}(2.5-4.6$

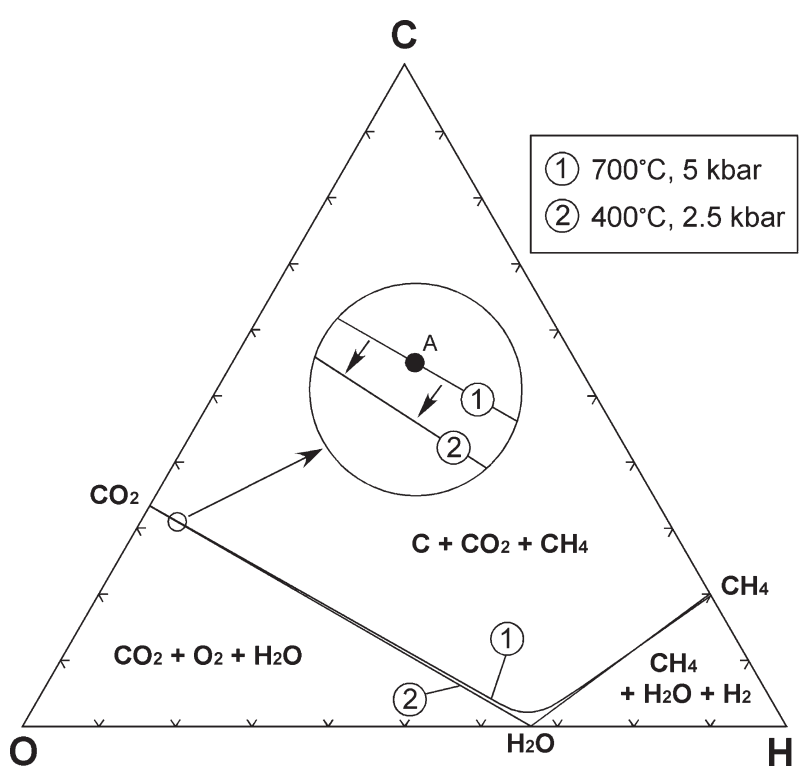

Figure 5. C-O-H diagram showing $\mathrm{CO}_{2}-\mathrm{CH}_{4}$ tile lines calculated at $700{ }^{\circ} \mathrm{C}, 5 \mathrm{kbar}$ and $400^{\circ} \mathrm{C}, 2.5 \mathrm{kbar}$. See text for further discussion. mol\%), $\mathrm{C}_{2} \mathrm{H}_{6}(0.01-0.02 \mathrm{~mol} \%)$, and $\mathrm{H}_{2}(0-0.05 \mathrm{~mol} \%)$. The occurrence of such ethane-bearing carbonic fluids is extremely rare in middle to lower crustal rocks, and has been reported only from a few localities, such as alkaline granites and associated hydrothermal veins in Greenland (Konnerup-Madsen et al., 1985). They reported $\mathrm{CO}_{2}-\mathrm{CH}_{4}$ gaseous inclusions with $0.6-0.1 \mathrm{~mol} \% \mathrm{C}_{2} \mathrm{H}_{6}$ within quartz in alkali granite and granite veins. Both $\mathrm{C}_{2} \mathrm{H}_{6}(2.1 \mathrm{~mol} \%)$ and $\mathrm{H}_{2}$ (3.2 mol\%) were detected only in $\mathrm{CH}_{4}$-rich inclusions within chkalovite in a hydrothermal vein. Our study therefore represents the first report of $\mathrm{C}_{2} \mathrm{H}_{6}{ }^{-}$and $\mathrm{H}_{2}$-bearing reduced fluid inclusions trapped in high-grade metamorphic rocks, as well as the first trace of $\mathrm{C}_{2} \mathrm{H}_{6}$ and $\mathrm{H}_{2}$ in $\mathrm{CO}_{2}$-rich fluid inclusions.

Our laser Raman analysis also identified a thin film of carbon (or nano-carbon) precipitated on the walls of the inclusion cavities as inferred from the Raman spectra shown in Figures $4 \mathrm{~g}$ and $4 \mathrm{~h}$. Such occurrence of carbon film have been found sometimes in methane-rich diagenetic fluid inclusions and more scarcely in $\mathrm{H}_{2} \mathrm{O}-\mathrm{CH}_{4}-\mathrm{CO}_{2}$ fluid inclusions associated with graphitic-bearing rocks but never in $\mathrm{CO}_{2}$-rich fluid inclusions. Experimentally, nanocarbon are produced by thermal decomposition of $\mathrm{CH}_{4}$ into $\mathrm{H}_{2}$ in presence of catalysts (see Shah et al., 2001; Homayonifar et al., 2008, and references therein), but this explanation is not relevant to this case study. The small amount of carbon precipitated along the inclusion wall suggests that the fluid oversaturation with respect to "graphite" was small during its precipitation, contrary to the re-equilibration experiments carried out by Pasteris and Chou (1998). The low ordering of carbon suggests that precipitation occurred at rather "low temperature" since both nucleation and growth of graphite require high activation energy (Ziegenbein and Johannes, 1980).

The carbon precipitation can be explained by the C-O-H phase relation calculated at $P-T$ conditions of the Limpopo rock during isochoric cooling of the inclusion as shown in Figure 5. The initial fluid is assumed to be at equilibrium with graphite and $\mathrm{CO}_{2}$-rich with minor $\mathrm{CH}_{4}$ as suggested from its present-day composition. Therefore, its approximate composition is plotted as spot " $\mathrm{A}$ " on the $\mathrm{CO}_{2}-\mathrm{CH}_{4}$ tie-line at $700{ }^{\circ} \mathrm{C}$ and $5 \mathrm{kbar}$ in the diagram. 
During isochoric cooling down to $400{ }^{\circ} \mathrm{C}$ and $2.5 \mathrm{kbar}$, the fluid-graphite equilibrium line moves slightly away from the carbon apex of the triangle towards the $\mathrm{O}-\mathrm{H}$ side. Spot " $\mathrm{A}$ " is then located inside the divariant field of $\mathrm{CO}_{2}+\mathrm{CH}_{4}+\mathrm{C}$. Thus, the fluid in the inclusion is slightly oversaturated with respect to graphite making possible the precipitation of carbon via the bulk reaction:

$$
\mathrm{CO}_{2}+\mathrm{CH}_{4} \rightarrow 2 \mathrm{C}+2 \mathrm{H}_{2} \mathrm{O}
$$

during retrograde metamorphism. The absence of graphite in the host rock suggests that the initial fluid at its $P-T$ conditions of trapping was not at saturation with this phase, which implies that the degree of oversaturation during cooling was even smaller, which is in favour of the low amount and low ordering state of precipitated carbon. The amount of water in the inclusion is thus partially overestimated due to carbon precipitation. However, as the amount of precipitated carbon is unknown, this overestimation remains unknown. Complete thermodynamic calculations to model fluid chemistry evolution during cooling should be done, including diffusion of $\mathrm{H}_{2}$ inside inclusion during retrograde metamorphism (Hall and Bodnar, 1990), to know what was the main process for graphite precipitation, the extent of increase in water concentration during cooling and thus to estimate whether low temperature analysis of inclusions are representative of trapped fluids.

Another interesting feature of laser Raman analysis is the presence of ethane and hydrogen in the fluid. However, they were not identified at the same temperature condition. At room temperature, $\mathrm{C}_{2} \mathrm{H}_{6}$ was detected, but at $150{ }^{\circ} \mathrm{C}$, we could detect $\mathrm{H}_{2}$ and $\mathrm{H}_{2} \mathrm{O}$, but not $\mathrm{C}_{2} \mathrm{H}_{6}$ (Fig. 4f). $\mathrm{H}_{2}$ is seldom identified in fluid inclusions from the $\mathrm{C}-\mathrm{O}-\mathrm{H}$ system because, during cooling, inside an inclusion considered as an isochoric and closed system, the concentration of minor species such as $\mathrm{CO}$ and $\mathrm{H}_{2}$ decreases at a level usually below the detection limit of micro-Raman spectroscopy (Dubessy et al., 1989). Ethane has been included in the calculation of graphite-fluid equilibrium (Zhang and Duan, 2009). Although these calculations were carried out at higher $P-T$ conditions, they demonstrate, as expected, that ethane concentration is significant only for $\mathrm{CH}_{4}$-rich fluids and reduced fluids in the redox range defined by the iron-wüstite and wüstite-magnetite buffers. Same remarks apply to the presence of molecular hydrogen. The presence of both $\mathrm{C}_{2} \mathrm{H}_{6}$ and $\mathrm{H}_{2}$ contradicts the fact that the fluid was $\mathrm{CO}_{2}$-rich at a redox state nearly the upper $f_{\mathrm{O}_{2}}$ limit of graphite stability. This suggests that the fluid composition analyzed presently does not represent an equilibrium composition, even frozen at higher temperature $\left(>400^{\circ} \mathrm{C}\right)$. The processes of the formation of $\mathrm{C}_{2} \mathrm{H}_{6}$ and $\mathrm{H}_{2}$ are thus not known. The disappearance of $\mathrm{C}_{2} \mathrm{H}_{6}$ during heating at $150{ }^{\circ} \mathrm{C}$ could be tentatively interpreted as a result of cracking of ethane into methane. However, this reaction proceeds within tenths of minutes, which seems to be very fast.

To conclude, the results of this study suggest that the $\mathrm{C}_{2} \mathrm{H}_{6}-\mathrm{H}_{2}-\mathrm{H}_{2} \mathrm{O}$-bearing carbonic fluid inclusions are a possible product of a series of reactions during post-peak decompression/cooling to room temperature. The formation of such fluids is mostly controlled by the precipitation of carbon on the inclusion wall due to overstepping of the $\mathrm{CO}_{2}-\mathrm{CH}_{4}$ binary fluid into the stability of $\mathrm{CO}_{2}+\mathrm{CH}_{4}+\mathrm{C}$ by rapid decompression/cooling (reaction (1)), and subsequent $\mathrm{C}-\mathrm{O}-\mathrm{H}$ reactions within the inclusion cavity during further decompression/cooling. Possible diffusion of $\mathrm{H}_{2}$ inside inclusion is not excluded.

\section{ACKNOWLEDGMENTS}

The analytical part of this study has been carried out when the first author visited Nancy in 2004 and 2009. Tsunogae thanks Université Henri Poincaré (Nancy Université), France, for facilities and support, and JSPS for travel grant. We thank Prof. van Reenen for providing samples for this study and Dr. N. Nishida for his assistance on microprobe analysis (JEOL JXA-8621 at the University of Tsukuba). We also thank Prof. M. Santosh and an anonymous reviewer for their review comments and Dr. T. Sawaki for his editorial handling. Partial funding for this project was produced by the Grant-in-Aid from the Japanese Ministry of Education, Sports, Culture, Science and Technology to Tsunogae (No. 20340148) and Prof. Osanai (No. 21253008), and JSPS-INSA Joint Research Program (No. BDD20023).

\section{DEPOSITORY MATERIALS}

Tables 1, 3, and Figure 2 are available online from http:// www.jstage.jst.go.jp/browse/jmps.

\section{REFERENCES}

Brown, P.E. (1989) FLINCOR: A microcomputer program for the reduction and investigation of fluid-inclusion data. American Mineralogist, 74, 1390-1393.

Brown, P.E. and Lamb, W.M. (1989) P-V-T properties of fluids in the system $\mathrm{H}_{2} \mathrm{O}-\mathrm{CO}_{2}-\mathrm{NaCl}$ : New graphical presentations and implications for fluid inclusion studies. Geochimica et Cosmochimica Acta, 53, 1209-1221.

Dubessy, J., Poty, B. and Ramboz, C. (1989) Advances in C-O-H$\mathrm{N}-\mathrm{S}$ fluid geochemistry based on micro-Raman spectroscopic analysis of fluid inclusions. European Journal of Mineralogy, 1, 517-534.

Eckhardt, G. and Wagner W.G. (1966) On the calculation of abso- 
lute Raman scattering cross sections from Raman scattering coefficients. Journal of Molecular Spectroscopy, 19, 407-411.

Hall, D.L. and Bodnar R.J. (1990) Methane in fluid inclusions from granulites: a product of hydrogen diffusion? Geochimica et Cosmochimica Acta, 54, 641-651.

Herzberg, G. (1945) Molecular Spectra and Molecular Structure II Infrared and Raman Spectra of Polyatomic molecules. pp. 632, Van Nostrand Reinhold Company, New York.

Homayonifar, P., Saboohi, Y. and Firoozabadi, B. (2008) Numerical simulation of nano- carbon deposition in the thermal decomposition of methane. International Journal of Hydrogen Energy, 33, 7027-7038.

Konnerup-Madsen, J., Dubessy, J. and Rose-Hansen, J. (1985) Combined Raman microprobe spectrometry and microthermometry of fluid inclusions in minerals from igneous rocks of the Gardar province (south Greenland). Lithos, 18, 271280.

Lapp, M. and Penney, C.M. (1977) Raman measurements in flames. In Advances in Raman Spectroscopy. (Clark, R.J.H. and Hester, R.E. Eds.). Wiley Heyden, London (UK), 3, 204-261.

Newton, R.C., Smith, J.V. and Windley, B. F. (1980) Carbonic metamorphism, granulites and crustal growth. Nature, 288, 45-50.

Nishimiya, Y., Tsunogae, T. and Santosh, M. (2008) Petrology and fluid inclusions of garnet-clinopyroxene rocks from Paramati in the Palghat-Cauvery Shear Zone System, southern India. Journal of Mineralogical and Petrological Sciences, 103, 354-360.

Ohyama, H., Tsunogae, T. and Santosh, M. (2008) $\mathrm{CO}_{2}$-rich fluid inclusions in staurolite and associated minerals in a highpressure ultrahigh-temperature granulite from the Gondwana suture in southern India. Lithos, 101, 177-190.

Pasteris, J.D. and Chou, I-M. (1998) Fluid deposited graphitic inclusions in quartz: Comparison between KTB (German Continental deep-Drilling) core samples and artificially reequilibrated natural inclusions. Geochimica et Cosmochimica Acta, 62, 109-122.

Schrötter, H.W. and Klöckner, H.W. (1979) Raman Scattering Cross Sections in Gases and Liquids. In Raman Spectroscopy of Gases and Liquids (Weber, A. Ed.). Springer Verlag, Berlin, 123-166.

Shah, N., Panjal, D. and Huffman, G.P. (2001) Hydrogen Production by Catalytic Decomposition of Methane. Energy \& Fuels, $15,1528-1534$.

Stevens, G. and van Reenen, D.D. (1992) Partial melting and the origin of metapelitic granulites in the Southern Marginal
Zone of the Limpopo Belt, South Africa. Precambrian Research, 55, 303-319.

Touret, J. (1971) Le facies granulite en Norwege Meridionale. Lithos, 4, 239-249.

Tsunogae, T., Miyano, T., van Reenen, D.D. and Smit, C.A. (2004) Ultrahigh-temperature metamorphism of the Southern Marginal Zone of the Archean Limpopo Belt, South Africa. Journal of Mineralogical and Petrological Sciences, 99, 213-224.

Tsunogae, T. and van Reenen, D.D. (2007) Carbonic fluid inclusions in sapphirine + quartz bearing garnet granulite from the Limpopo Belt, southern Africa. Journal of Mineralogical and Petrological Sciences, 102, 57-60.

Tsunogae, T., Santosh, M., Osanai, Y., Owada, M., Toyoshima, T. and Hokada, T. (2002) Very high-density carbonic fluid inclusions in sapphirine-bearing granulites from Tonagh Island in the Archean Napier Complex, East Antarctica: implications for $\mathrm{CO}_{2}$ infiltration during ultrahigh-temperature $(T>$ $1100^{\circ} \mathrm{C}$ ) metamorphism. Contributions to Mineralogy and Petrology, 143, 279-299.

Tsunogae, T., Santosh, M. and Dubessy, J. (2008) Fluid characteristics of high- to ultrahigh-temperature metamorphism in southern India: a quantitative Raman spectroscopic study. Precambrian Research, 162, 198-211.

Van den Berg, R. and Huizenga, J. (2001) Fluids in granulites of the Southern Marginal Zone of the Limpopo Belt, South Africa. Contributions to Mineralogy and Petrology, 141, 529-545.

Van Reenen, D.D. and Hollister, L.S. (1988) Fluid inclusions in hydrated granulite facies rocks, southern marginal zone of the Limpopo Belt, South Africa. Geochimica et Cosmochimica Acta, 52, 1057-1064.

Wopenka, B. and Pasteris, J.D. (1986) Limitations to quantitative analysis of fluid inclusions in geological samples by laser Raman microprobe spectroscopy. Applied Spectroscopy, 40, 144-151.

Zhang, C. and Duan, Z. (2009) A model for C-O-H fluid in the Earth's mantle. Geochimica et Cosmochimica Acta, 73, 20892102.

Ziegenbein, D. and Johannes, W. (1980) Graphite in C-HO fluids: An unsuitable compound to buffer fluid composition at temperatures up to $700{ }^{\circ} \mathrm{C}$. Neues Jahrbuch für MineralogieMonatshefte, 7, 289-305.

Manuscript received June 22, 2009

Manuscript accepted August 25, 2009

Manuscript handled by Takayuki Sawaki 